http://dx.doi.org/10.12775/szhf.2013.056

\author{
Dawid Kolasa
}

\title{
Pluralizm w filozofii religii Karla Jaspersa
}

Obydwa sformułowania występujące w tytule niniejszego artykułu wymagają doprecyzowania. Po pierwsze, należy wskazać co rozumiemy pod hasłem „filozofia religii Karla Jaspersa”, po drugie, omówić trzeba jej pluralistyczny charakter. Jaspers określał swą filozofię w jej całokształcie, zarówno pod względem metody, jak i treści myślenia, mianem wiary filozoficznej. Ten fakt oraz obecność w jego tekstach wyrażeń tradycyjnie zarezerwowanych dla dziedziny religii sprawiły, że jego filozofia narażona została na dwojakiego rodzaju ataki. Pojawiały się głosy sugerujące, że myśl ta jest „nie dość świecka”, a obecne w jej obrębie podobieństwa do doktryny chrześcijańskiej stanowią zbędny balast ${ }^{1}$. $\mathrm{Z}$ drugiej strony, oskarżano Jaspersa o nieuprawnione zapożyczenie pewnych kategorii religijnych; a ponieważ starym pojęciom niejednokrotnie przypisywał odbiegające od potocznych (co nie znaczy, że zupełnie nowe) znaczenia, to miał $\mathrm{w}$ ten sposób dopuszczać się niewybaczalnych

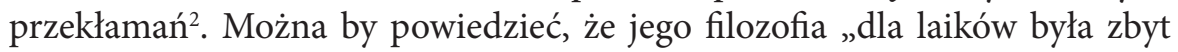
podobna do religii, a dla wierzących zbyt zlaicyzowana".

\footnotetext{
${ }^{1}$ Najdosadniej wyraził to Sartre, pisząc w liście do Garaudy’ego, że „Myśl Jaspersa jest teologią, która nie ma odwagi się do tego przyznać”: J.-P. Sartre, List: Marksizm a filozofia egzystencji, [w:] R. Garaudy, Perspektywy człowieka, tłum. Z. Butkiewicz, J. Rogoziński, Książka i Wiedza, Warszawa 1968, s. 124.

${ }^{2}$ Taką perspektywę przyjął między innymi Gabriel Marcel: tenże, Sytuacja podstawowa i sytuacje graniczne u Karla Jaspersa, [w:] tenże, Od sprzeciwu do wezwania, tłum. S. Ławicki, Instytut Wydawniczy PAX, Warszawa 1965. W tym samym nurcie można by chyba umieścić
} 
Dla przykładu jeden z odczytów radiowych wydanych potem jako fragment Wprowadzenia do filozofii nosi tytuł Idea Boga i dopiero lektura innych tekstów Jaspersa pozwala zdać sobie sprawę, że owa idea (w wydaniu Jaspersowskim) nie pokrywa się z wyobrażeniem obecnym $\mathrm{w}$ jakiejkolwiek religii ${ }^{3}$. Podobnie ma się sprawa $\mathrm{z}$ jednym $\mathrm{z}$ podstawowych sformułowań zawartych w Wierze filozoficznej: Bóg jest ${ }^{4}$. Owszem, ale nie jest to Bóg, który został objawiony w jakiejkolwiek religii. Znajduje to wyraz w ostatniej wielkiej pracy niemieckiego filozofa, gdzie jednoznacznie pisze on: „Nie wierzę w objawienie i nigdy, o ile pamiętam, nie wierzyłem choćby tylko w jego możliwość ". Jak więc Jaspers może pisać o religii, skoro w punkcie wyjścia odrzuca sam rdzeń wierzeń religijnych? Otóż dokonuje przeniesienia akcentów, jak bowiem czytamy kilka linijek wcześniej:

Objawienia nie można badać jako zjawiska empirycznego, natomiast niewątpliwie można takim badaniom poddać wiarę w objawienie. Wówczas mówi się jednak nie o rzeczywistości i prawdzie objawienia, lecz tylko o realności wiary w objawienie ${ }^{6}$.

W przypadku Jaspersa mamy zatem do czynienia ze specyficzną formą „filozofii religii", gdyż bada fenomeny, których prawdziwość, w sensie ścisłym ${ }^{7}$, nie jest istotna.

również polskiego badacza Antoniego Szweda, który dość krytycznie odnosi się do Jaspersowskiej koncepcji szyfrów transcendencji, por. A. Szwed, Wokół transcendencji. Karl Jaspers w sporze $z$ chrześcijaństwem, [w:] Karl Jaspers: człowiek w epoce przełomu, red. Cz. Piecuch, Wydawnictwo Naukowe Uniwersytetu Pedagogicznego, Kraków 2013, s. 86-99. Inne przykłady tego rodzaju krytyki filozofii Jaspersa wskazywał już wybitny znawca jego filozofii: R. Rudziński, Człowiek w obliczu nieskończoności. Metafizyka i egzystencja w filozofii Karla Jaspersa, Książka i Wiedza, Warszawa 1980, s. 227.

${ }^{3}$ K. Jaspers, Wprowadzenie do filozofii. Dwanaście odczytów radiowych, tłum. A. Wołkowicz, Siedmioróg, Wrocław 1998, s. 26-34.

${ }^{4}$ Tenże, Wiara filozoficzna, tłum. A. Buchner i inni, Wydawnictwo COMER, Toruń 1995, s. 27.

${ }^{5}$ Tenże, Wiara filozoficzna wobec objawienia, tłum. G. Sowiński, Wydawnictwo ZNAK, Kraków 1999, s. 38.

${ }^{6}$ Tamże, s. 38. Najradykalniejsza deklaracja pada jednak w kolejnych rozdziałach: „W sensie realności istnienia Bóg nie istnieje”. Tamże, s. 322. Nie zmienia to faktu, że wiara w Boga wciąż pozostaje tematem rozważań Jaspersa.

7 „Ścisły” sens prawdziwości, o którym tu piszę można wstępnie utożsamić z prawdziwością w rozumieniu naukowym, czyli jako głoszenie falsyfikowalnych twierdzeń o rzeczywistości. W dalszej części tekstu dokonam niezbędnych uzupełnień. 
Dlatego właśnie zapytywania, czy Jaspersa można, czy nie należy nazywać „egzystencjalistą chrześcijańskim” są zupełnie jałowe, należałoby skwitować je stwierdzeniem zaczerpniętym z Mouniera, że „[Jaspers] nie może nawet być nazwany filozofem chrześcijańskim, choć wszystkie drgnienia jego myśli, z wyjątkiem może ostatniego, dokonują się w samym miąższu chrześcijaństwa ${ }^{8 ”}$. Z pewnością jest Jaspers filozofem „zachodnim”, gdyż nawet, gdy jego niektóre postulaty stają się tożsame z naukami myślicieli Wschodu, to wciąż jest w większym stopniu spadkobiercą Świętego Augustyna niż Buddy9. Natomiast chrześcijaństwo przez stulecia było „religią europejską” i w takim właśnie duchowym klimacie kształtowała się myśl Jaspersa.

Stwierdzenia o „chrześcijańskości Europy” nie należy uważać za głos $\mathrm{w}$ (chyba już zresztą wygasłym) sporze o invocatio dei w preambule do polskiej czy europejskiej Konstytucji. Wskazuję tylko, że, niezależnie od moralnej czy jakiejkolwiek innej oceny tego faktu, chrześcijaństwo miało wyraźny wpływ na obecny kształt naszego kontynentu i ukształtowało wiele istniejących tu prądów umysłowych. Dlatego nie ma większego znaczenia, że Jaspers nie był aktywnym członkiem Kościoła ${ }^{10}$, gdyż nie zmienia to faktu, że bez odniesień do tradycji chrześcijańskiej filozofować nie potrafił, i to nawet jeśli odniesienia te były niejednokrotnie negatywne. Sam filozof pisał o tym w następujący sposób:

${ }^{8}$ E. Mounier, Wprowadzenie do egzystencjalizmów, [w:] Wprowadzenie do egzystencjalizmów oraz wybór innych prac, tłum. J. Zabłocki, Znak, Kraków 1964, s. 222. Por. M. Sopoliński, Między filozofia a chrześcijaństwem. Z filozofii religii Karla Jaspersa, „Filozofia religii”, t. 1, Poznań 2005, s. 63-70.

${ }^{9}$ Istnieją autorzy, którzy dokładnie zbadali podobieństwa występujące pomiędzy filozofią egzystencji Jaspersa a duchowymi wskazaniami mędrców Wschodu, dlatego nie będę tu powtarzał szczegółowych analiz, por. M. Żelazny, Filozofia i psychologia egzystencjalna, Wydawnictwo Naukowe UMK, Toruń 2011, s. 97-104 (rozdział Egzystencja i dług karmiczny); I. Sarin, Karl Jaspers and Asian thought: Buddda and Nagarjuna, [w:] K. Salamun, G. Walters, Karl Jaspers philosophy: Expositions \& interpretations, Humanity Books, Amherst, New York 2008, s. 291-312. Problem związku filozofii Jaspersa z myśleniem Wschodu podejmowany był, wprawdzie z różnym skutkiem, jeszcze za życia filozofa, por. M. K. Malhorta, Die Philosophie Karl Jaspers' und die indische Philosophie, „Zeitschrift für philosophische Forschung” 1961, s. 363-373.

${ }^{10}$ Został jednak ochrzczony (12 kwietnia 1883) i poddany sakramentowi bierzmowania (20 marca 1898), choć sam wspomina, że jego rodzice zasadniczo ignorowali Kościół i przyjęcie sakramentów nastąpiło raczej „dla zachowania zwyczaju”. Patrz: K. Jaspers, Autobiografia, tłum. S. Tyrowicz, Wydawnictwo COMER, Toruń 1993, s. 109; S. Kirkbright, Karl Jaspers. A biography. Navigations in truth, Yale University Press, New Haven and London 2004, s. 282. 
My, mieszkańcy Zachodu, wszyscy pozostajemy chrześcijanami, ponieważ ukształtowaliśmy się na tym obszarze, ponieważ chrześcijański rodowód porusza naszą duszę, określa nasze decyzje i zamierzenia, ponieważ napełniają nas obrazy i wyobrażenia, które mają swe źródło w Bibliii ${ }^{11}$.

Stanowi to o specyfice myślenia Jaspersa. Otóż gdy pisze on o szyfrach transcendencji, to dokładnej analizie poddaje $\mathrm{w}$ zasadzie tylko szyfry pochodzące $\mathrm{z}$ Biblii ${ }^{12}$, natomiast wnioski dotyczące relacji pomiędzy filozofią a religią (zarówno w perspektywie jednostki, jak i społeczeństwa) odnosić się mają do wszelkich form myślenia religijnego. Innymi słowy: spośród wszystkich wielkich religii właśnie chrześcijaństwo było głównym punktem odniesienia dla Jaspersowskich analiz dotyczących szyfrów transcendencji, natomiast rezultaty tych rozważań miały, w oczach filozofa, mieć na tyle uniwersalny charakter, że dałoby się je przenieść na grunt jakiejkolwiek innej religii. $\mathrm{W}$ pewnym sensie świadczy o tym umieszczenie $\mathrm{w}$ jednym szeregu Sokratesa, Buddy, Konfucjusza i Jezusa. Należy jednak pamiętać, że wspólna tym czterem autorytetom wielkość nie miała swego źródła w kulcie religijnym, mimo iż trzej z nich zapoczątkowali istotne ruchy religijne. Wynikała ona raczej z tego, że:

Te cztery osobowości zdobyły autorytet dzięki swym postawom, czynom, doświadczeniom bytu i wymaganiom, na które odtąd kierują spojrzenie filozofujący ludzie [...]. Każdy z nich wywarł jak największy wpływ na filozofię, która później powstawała na obszarach jego oddziaływania.

[...] nie odpowiadali typowi proroka, [...] uważają, że posługują bóstwu, przez które zostali powołani lub pozostają w służbie niesienia świętości. Głoszonych przez siebie treści nie zawdzięczają jednak bezpośredniemu objawieniu; [...] w nich coś nagle się rozpoczyna ${ }^{13}$ [wyróżnienie D. K.].

${ }^{11}$ K. Jaspers, Wiara filozoficzna wobec objawienia, s. 60.

${ }^{12} \mathrm{~W}$ Wierze filozoficznej wobec objawienia oraz w poświęconych temu zagadnieniu wykładach analizuje Jaspers: szyfr Boga jedynego, szyfr Boga osobowego, szyfr wcielenia, a także m.in. szyfr piekła, por. K. Jaspers, Wiara filozoficzna wobec objawienia; tenże, Szyfry transcendencji, tłum. Cz. Piecuch, Wydawnictwo COMER, Toruń 1995.

${ }^{13}$ K. Jaspers, Autorytety. Sokrates, Budda, Konfucjusz, Jezus, tłum. P. Bentkowski, R. Flaszak, Wydawnictwo KR, Warszawa 2000, s. 155-156, por. także Ch. Courtney, Jaspers meets Confucius, [w:] Philosophical faith and the future of humanity, ed. H. Wautischer, A. Olson, G. Walters, Springer, Dordecht - Heidelberg - London - New York 2012, s. 203-209; Y.-D. Chung Hanyu, Karl Jaspers and Asian thought: Lao-Tzu and Confucius, [w:] K. Salamun, G. Walters, Karl Jaspers philosophy: Expositions \& interpretations, s. 313-335; A. Olson, Jesus as "Paradig- 
Wspomniane doświadczenia staną się jaśniejsze po zaprezentowaniu kolejnych elementów filozofii Jaspersa, o których napiszę w dalszej części tekstu.

Quasi-uprzywilejowana pozycja chrześcijaństwa w tekstach autora Wiary filozoficznej nie wynika zatem z jakiejś przewagi tej religii nad innymi, ale stąd, że samemu Jaspersowi łatwiej było badać szyfry, z którymi obcował na co dzień.

Jeśli zaś chodzi o tytułowy pluralizm, to pierwszym krokiem ku niemu jest Jaspersowska kategoria prawdy egzystencjalnej, która sprawia, że różnorakie szyfry, pochodzące $\mathrm{z}$ różnych religii i w nich występujące, mogą odgrywać analogiczną rolę podczas rozjaśniania egzystencji.

$\mathrm{Na}$ gruncie filozofii Jaspersa o pojęciu prawdy można mówić w wielu znaczeniach, spośród których najbardziej istotne są w tym miejscu: prawda naukowa oraz prawda egzystencjalna. Podstawowa różnica między nimi polega na tym, że choć ta pierwsza jest sprawdzalna, weryfikowalna za pomocą powszechnie akceptowanych narzędzi i metod, to nie ma mocy, aby rozjaśnić egzystencję. Dzięki nauce można bowiem poznać człowieka, jako przedmiot wśród innych przedmiotów, ale nie można nauczyć się być sobą. Żartobliwie można by powiedzieć, że „dzięki twierdzeniu Pitagorasa nikt jeszcze nie stał się lepszym człowiekiem”. Prawdy głoszone na gruncie nauki obowiązują powszechnie (to znaczy wszędzie tam, gdzie zostały dokonane adekwatne badania), ale nie bezwarunkowo (gdyż każda prawda naukowa może zostać obalona za pomocą kolejnych badań), natomiast prawda egzystencji jest w najwyższym stopniu subiektywna, ale za to absolutna, przez co należy rozumieć podstawowe znaczenie tego słowa - jest nieuwarunkowana, czyli niezależna od niczego poza nią samą. Prawda egzystencjalna jest czymś, co pozwala człowiekowi uświadomić sobie swą wolność i zacząć egzystować autentycznie $^{14}$. Dla Jaspersa prawdą egzystencjalną było na przykład to, że istnieje „bezwarunkowy obowiązek”, którego realizacja pozwala urzeczywistniać swą egzystencję. Istnienia takowego obowiązku nie sposób oczywiście udowodnić w sposób naukowy ${ }^{15}$.

matic individual" in Karl Jaspers' Great Philosophers, vol. 1, "Existenz. An international journal in philosophy, religion, politics and the arts", vol. 2, 2007, s. 19-23.

${ }^{14}$ Tematyka ta jest przedmiotem przede wszystkim Rozumu i egzystencji, por. K. Jaspers, Rozum i egzystencja, [w:] tenże, Rozum i egzystencja. Nietzsche i chrześcijaństwo, tłum. Cz. Piecuch, Wydawnictwo Naukowe PWN, Warszawa 1991.

${ }^{15}$ Oczywiście nie sposób nie dostrzec w tej kategorii inspiracji Kierkegaardem, który w Bojaźni i drżeniu pisał o „teleologicznym zawieszeniu etyki”. Co ciekawe, gdy duński filozof pisze, że „bezwarunkowy obowiązek jest obowiązkiem wobec Boga”, a Jaspers odnosi ów obowiązek 
Osiągnąć prawdę egzystencjalną (rozjaśnić egzystencję), można na rozmaite sposoby. Podstawowym jest komunikacja egzystencjalna $\mathrm{z}$ drugim człowiekiem ${ }^{16}$, drugim, zapewne bardziej spektakularnym, aczkolwiek zarazem nietrwałym przeżywanie sytuacji granicznych ${ }^{17}$. Podobną rolę może odgrywać obcowanie z szyframi transcendencji, jednak do tego konieczne jest uchwycenie właśnie ich szyfrowego charakteru, co oznacza zaprzestanie traktowania ich jako cielesne przejawy obecności jakiejś transcendencji w świecie. Taki postulat stanowi źródło nieustannego konfliktu, który można zaobserwować pomiędzy filozofią a religią, przy czym mam w tym momencie na myśli raczej rozróżnienie „filozoficznego” (egzystencjalnego) i religijnego (bezpośredniego) odczytania przekazów płynących na przykład z Biblii.

Jaspers wiele miejsca poświęca wskazaniu różnic i barier pomiędzy filozofią a religią, tutaj wymienię tylko te najbardziej istotne. Charakterystyczna dla większości religii jest wiara $\mathrm{w}$ istniejący $\mathrm{w}$ innym wymiarze, często spersonifikowany, absolut, będący gwarantem i źródłem ładu tego świata i nieodłącznie z tym związane dążenie do zbawienia, które ma nastąpić $\mathrm{w}$ tak zwanym życiu przyszłym, to jest po śmierci ziemskiej. Jaspers również posługuje się pojęciem transcendencji, jest bowiem świadomy, że człowiek nie może zawdzięczać swojego życia i swojej wolności samemu sobie, jednakże nie nadaje tej transcendencji imienia jakiegokolwiek boga. „Zbawienie” zaś jest możliwe tylko w świecie doczesnym, to znaczy jest nim uczynienie siebie lepszym człowiekiem, wykorzystanie tu i teraz tkwiących w sobie możliwości. Po śmierci nie ma nic, marzenia o życiu wiecznym są tylko efektem lęku i nieumiejętności pogodzenia się z granicznością śmierci ${ }^{18}$.

Pisząc o religiach, Jaspers wskazuje ich wspólnotowy charakter (przeciwstawiany jednostkowemu przeżywaniu doświadczeń egzystencjalnych),

do siebie samego, to obaj de facto mają na myśli niemal to samo. Szerzej na ten temat patrz: D. Kolasa, Bezwarunkowy obowiązek jako przejaw wolności w filozofii Karla Jaspersa, [w:] Karl Jaspers. Myślenie zaangażowane, red. Cz. Piecuch, Wydawnictwo Naukowe Uniwersytetu Pedagogicznego, Kraków 2011, s. 36-44.

${ }^{16} \mathrm{Na}$ ten temat wygłaszałem podczas „II Ogólnopolskiej Konferencji Monoseologicznej” referat $O$ możliwości komunikacji egzystencjalnej na gruncie filozofii Karla Jaspersa. W 2014 roku spodziewana jest publikacja książki, w której zamieszczony będzie tekst tegoż wystąpienia.

${ }^{17}$ Problematyka sytuacji granicznych jest bodaj najlepiej opracowanym zagadnieniem spośród wszystkich, którymi zajmował się Jaspers, patrz: D. Kolasa, Sytuacje możliwe a sytuacje graniczne w filozofii Karla Jaspersa, „Studia z Historii Filozofii”, nr 1, Toruń 2009, s. 135-145.

${ }^{18}$ K. Jaspers, Sytuacje graniczne, tłum. A. Staniewska, M. Kwieciński, [w:] R. Rudziński, Jaspers, Wiedza Powszechna, Warszawa 1978, s. 205. 
a także konieczność duchowego (chyba nie tylko) poddania się przykazom autorytetów religijnych. Takie oddanie swej wolności w czyjejś ręce byłoby oczywiście w oczach Jaspersa zaprzestaniem filozofowania, ono bowiem wymaga brania pełnej odpowiedzialności za swoje decyzje. Pozostaje wciąż otwarty problem, na który Jaspers nie zwrócił specjalnej uwagi. Można przecież zadać pytanie o to dlaczego mielibyśmy przyjąć, że szukanie wytycznych dla swego postępowania w autorytecie (religijnym, ale nie tylko, takim autorytetem może do pewnego stopnia być etyka Kanta lub cokolwiek innego) z konieczności jest wyrzeczeniem się wolności? Czy na pewno „bycie sobą” zmusza nas do porzucenia wszelkiej tradycji? Oczywiście to pytanie należałoby raczej zadać Nietzschemu, a nie Jaspersowi, bo w tym aspekcie właśnie od autora Tako rzecze Zaraturstra czerpie on najwięcej ${ }^{19}$.

Filozofujący człowiek nie uważa, że jego przekonania (np. wiara w to, że przejawem jego wolności jest podejmowanie działań bezwarunkowych) wynikają z jakiegoś dostępnego w pewien specyficzny sposób boskiego porządku. Bóg filozofów pozostanie zawsze bogiem ukrytym. Dialog z nim przybiera postać bezgłośnej kontemplacji, podczas gdy Bóg, tak jak rozumieją go religie, przemawia do wiernych wprost ${ }^{20}$. Nie to jednak stanowi źródło konfliktów (zarówno na linii religia-filozofia, jak i pomiędzy poszczególnymi wyznaniami), wynikają one raczej przekonania o „jedyności” tego właśnie objawienia. Jaspers wielokrotnie podkreśla, że dla człowieka wierzącego termin „objawienie” nie jest i nie może być pojęciem ogólnym. „Objawienie w ogóle" byłoby z tej perspektywy sprzecznością, a to dlatego, że autentyczne jest tylko jedno jedyne „Objawienie”, które dzięki swej jedyności zasługuje, by pisać o nim wielką literą.

Pomiędzy filozofią i religią z konieczności występuje napięcie. Nie może ono być zniesione przez to, że któraś z nich zostanie wyparta. Ocena religii z punktu widzenia filozofii (i odwrotnie) zawsze jest nieobiektywna, bo nie uwzględnia specyficznego dla niej samej punktu widzenia. Od wieków filozo-

${ }^{19}$ Czytelnikowi zainteresowanemu problemem „bycia sobą” polecam artykuł: A. Węgrzecki, Wolność i bycie sobą, [w:] Cz. Piecuch, Karl Jaspers. Myślenie zaangażowane, s. 13-24, jednak równolegle powinien się on zapoznać z tekstem: J. Krupiński, Homo schistos: soba (nie) bycie, [w:] Cz. Piecuch, Karl Jaspers. Człowiek w epoce przełomu, s. 138-169. Wówczas sam będzie mógł zadecydować, czy wizja Węgrzeckiego przekonuje go bardziej niż, demistyfikująca tę pierwszą jako metafizykę, interpretacja Krupińskiego. Dla niniejszych rozważań zagadnienie to ma charakter marginalny.

${ }^{20}$ K. Jaspers, Wiara filozoficzna, s. 59. 
fia i religia pobudzały się nawzajem i taka właśnie rola rysuje się przed nimi w przyszłości:

Z powodu swej obcości wobec religii filozofia nie może jednak zwalczać jej jako nieprawdziwej, gdy pozostaje ona wierna swemu źródłu. Filozofowanie uznaje religię za prawdę, której nie rozumie, ale trwa w stałej gotowości, w stawiającej pytania woli rozumienia. Być poruszanym przez nią stale na nowo - to należy do życia samej filozofii. Stosunek między filozofią a religią jest walką, w której filozofia ze swej strony składa broń w obliczu tego, co rozstrzygające, a niepojęte ${ }^{21}$.

Próbując wskazać na czym miałoby polegać owo „filozoficzne” odczytanie przekazów religijnych, w pierwszej kolejności napotykamy pytanie: czy i w jaki sposób religia może być nośnikiem prawdy egzystencjalnej? To natomiast odsyła do jeszcze szerszego zagadnienia, mianowicie do „prawdziwości” (w jakimkolwiek znaczeniu) przekazów religijnych.

Pojęcie „prawdy religijnej” może odnosić się do tego, co dana religia uważa za prawdziwe w odniesieniu do świata, w odróżnieniu od treści, które na temat religii formułują inne dyscypliny. W tym aspekcie Jaspers bardzo krytycznie odnosi się do wszelkich doktryn religijnych, jego zdaniem badania historyczne oraz współczesna wiedza na temat funkcjonowania przyrody pozwalają obalić wszelkie religijne roszczenia i pewnością gdyby tylko o taką prawdziwość chodziło, to żadna religia nie znalazłaby się w obrębie zainteresowania filozofa. Nauka przynosi bowiem o wiele bardziej adekwatny obraz świata i jej ustalenia są niepodważalne ze stanowiska religii.

Wiadomo jednak, że to nie kosmologia jest sednem wszelkich religii (problem istnienia Boga, będącego pierwszą przyczyną/gwarantem/zegarmistrzem/świadkiem światowego porządku pozwalam sobie zaliczyć do kwestii kosmologicznych, gdyż włącza się on w obręb zagadnienia „jaki jest świat i na czym się opiera"). Gdyby tak było, to wszystkie wyznania byłyby fałszywe. W tym aspekcie Jaspers jest konsekwentnym empirystą: ponieważ niemożliwe jest podanie warunków koniecznych dla przeżycia doświadczeń wskazujących na obcowanie z inną niż ziemska rzeczywistością, to wszelkie tego rodzaju pseudo-przeżycia należy wyrzucić z obszaru zainteresowań badawczych. Jeśli natomiast chcemy badać takie doświadczenia, to w pierwszej kolejności należy zapoznać się ze stanem zdrowia psychicznego osoby je

${ }^{21}$ K. Jaspers, Filozofia egzystencji, tłum. D. Lachowska, [w:] tenże, Filozofia egzystencji, Państwowy Instytut Wydawniczy, Warszawa 1990, s. 155. 
przeżywającej, mogą one bowiem być skutkiem postępujących patologicznych procesów psychicznych. Taką diagnozę Jaspers sformułował między innymi w odniesieniu do Emmanuela Swedenborga. Zdaniem niemieckiego filozofa (nie zapominajmy - również psychiatry z wieloletnim doświadczeniem) „transcendentne” przeżycia szwedzkiego mistyka wyczerpują znamiona schizofrenii. Nie można jednak popadać w przesadę. Nie jest bowiem tak, jakoby wszystkie przeżycia mistyczne miały charakter chorobowy. Jaspers jednoznacznie pisze:

[...] wielkich mistyków, których nawiedzały myśli schizofreniczne (Plotyn, Mistrz Eckhart, Tomasz z Akwinu), nie należy ujmować ani jako schizofreników, ani w ogóle jako osobników nienormalnych ${ }^{22}$.

Odróżnienie przeżyć, których wytwory mogą odgrywać następnie istotną rolę w kształtowaniu kultury duchowej ${ }^{23}$, od doświadczeń stricte patologicznych jest bardzo skomplikowanym, a zarazem wymagającym wiele delikatności zadaniem. Przykładem jest postać i twórczość Sørena Kierkegaarda. Jaspers dokonywał drobiazgowej analizy jego dzienników, w których przejawy choroby niejednokrotnie mieszały się z przebłyskami głębokiego uchwycenia sensu transcendencji, nie wspominając już o literackim geniuszu. Trudno bowiem o jednoznaczną interpretację na przykład takiego sformułowania:

Postrzegałem to [swoją chorobę - przyp. D. K.] jako najwyższą cenę, którą musiałem zapłacić Wszechmogącemu Bogu za intelektualną moc, która nie miała sobie równych wśród współczesnych. Nie popadłem przez to w pychę, gdyż już dawno zostałem zmiażdżony ${ }^{24}$.

Mając świadomość skomplikowania tego problemu, Jaspers nie podejmował się zresztą jednoznacznej interpretacji relacji pomiędzy ewentualną chorobą psychiczną Kierkegaarda a jego myśleniem o transcendencji. W Die grossen Philosophen czytamy:

${ }^{22}$ K. Jaspers, Strindberg $i$ Van Gogh, tłum. R. Reszke, Wydawnictwo KR, Warszawa 2006, s. $155-156$.

${ }^{23}$ Czyli takich doświadczeń, które sprawiły, że powstały na przykład dzieła literackie mogące pełnić funkcję szyfrów transcendencji.

${ }^{24}$ S. Kierkegaard, Die Tagebücher, tłum. z duńskiego na niemiecki i redakcja naukowa Theodor Haecker, Brenner Verlag, Innsbruck 1923, s. 277, cyt. za K. Jaspers, Die großen Philosophen. Nachlass Bd 1, Darstellungen und Fragmente, zebrane i zredagowane przez Hansa Sanera, Piper, München 1981, s. 446. 
[...] również tutaj napotykamy ciekawą zależność dwu pierwiastków: sens chrześcijańskiego cierpienia jako ekspresji prawdy chrześcijańskiej egzystencji oraz sens chorobowego cierpienia - melancholia Kierkegaarda jako wyraz jego chrześcijańskiej prawdy, zarówno jako pokutnika, jak i tego, wobec którego dokonuje się pokuty ${ }^{25}$.

Zagadnienie to jest oczywiście o wiele szersze niż ujęcie zaprezentowane na poprzednich stronach. Przejdę teraz do kolejnego określenia religii. Istotniejszym niż kosmologia, a nawet ważniejszym niż kwestia istnienia Boga zagadnieniem każdej chyba religii jest zbawienie ludzkiej duszy. Religie formułują nakazy, których respektowanie czyni człowieka „godnym” życia wiecznego.

Mówienie o „zbawieniu” rozumianym dosłownie spotkałoby się z taką samą krytyką Jaspersa, jak twierdzenia o „niebie”; interpretuje on zbawienie $\mathrm{w}$ sensie egzystencjalnym. Stawia następujące pytanie: czy nauki dawane ludziom przez religie mogą ułatwić im rozjaśnienie egzystencji? Czy etyka mająca swoje źródło w religii może komuś pomóc stać się lepszym człowiekiem? Czy można w taki sposób zinterpretować na przykład zmartwychwstanie Jezusa, że nawet gdy odrzucimy historyczność tego faktu, to wciąż będzie do nas przemawiał? A jeśli na ostatnie pytanie odpowiemy twierdząco, to czy to, co wówczas pozostanie, będzie miało cokolwiek wspólnego z religią?

W czwartej części Wiary filozoficznej wobec objawienia Jaspers dokonuje rozróżnienia pomiędzy pojęciami odnoszącymi się do świata, znakami egzystencji, symbolami i szyframi transcendencji.

Pojęcia uchwytują i ujmują myślowo to wszystko, co ma charakter zjawiska. Znaki utrafiają w to wszystko, czym właściwie jestem i mogę być jako ja sam. Szyfry uobecniają to wszystko, co jest właściwą rzeczywistością i co staje się doświadczalne jedynie dla egzystencji ${ }^{26}$.

Mówiąc krótko, rolą znaków jest uzyskanie samoświadomości przez egzystencję. Jak wiadomo egzystencja nie jest zjawiskiem i nigdy nie ukazuje się świadomości w ogóle (Jaspersowska Bewusstsein überhaupt), jest natomiast

\footnotetext{
${ }^{25}$ Tamże, s. 447. Ostatecznie rozwiązaniem „Problemu Kierkegaarda” będzie dla Jaspersa, cytując tytuł jednego z podrozdziałów pracy poświęconej autorowi Albo-Albo „(uchwycenie) wielkości Kierkegaarda jako interpretacyjnego przekształcenia rzeczywistości choroby”. Czytelnik może zapoznać się z tym fragmentem w: tamże, s. 450-453. W polskim wydaniu tekst ten dostępny jest w książce K. Jaspers, Kierkegaard, która w tłumaczeniu prof. Tomasza Kupsia i moim ukaże się wkrótce nakładem Wydawnictwa Naukowego UMK.

${ }^{26}$ K. Jaspers, Wiara filozoficzna wobec objawienia, s. 192.
} 
odczuwana w sposób bezpośredni. Egzystencji nie da się uchwycić w sensie poznawczym, gdyż każde takie ujęcie byłoby jej uprzedmiotowieniem, czyli na gruncie przesłanek Jaspersa unicestwieniem. Można jednak na egzystencję wskazywać za pomocą znaków, do których zaliczamy między innymi wolność, historyczność czy otwartość na komunikację.

Szyfry są natomiast możliwe do uchwycenia tylko dla egzystencji, czyli o tyle, o ile jestem wolnością, a z drugiej strony, w przeciwieństwie do symbolu, nie można w ich przypadku mówić o jakiejś „drugiej stronie”. Symbol odsyła do czegoś innego niż on sam i dzięki temu odniesieniu nabiera znaczenia, natomiast szyfr nie koresponduje z niczym na zewnątrz niego:

[...] znak niech będzie definiowalnym znaczeniem czegoś innego niż sam znak i dostępnego również bez pośrednictwa znaku [w przypadku egzystencji możliwe jest jej odczucie, które wyprzedza jakąkolwiek wypowiedź na jej temat, nie mówiąc już o refleksyjnej analizie - przyp. D. K. $\left.{ }^{27}\right]$; symbol niech będzie obecnością czegoś innego niż sam symbol, obecnością w naocznościowej pełni, w której oznaczanie i oznaczane pozostają nierozdzielną jednością, a symbolizowana treść istnieje dopiero w samym symbolu; szyfr niech będzie mową transcendencji, która jest dostępna tylko dzięki mowie, a nie dzięki tożsamości rzeczy i symbolu, jaka cechuje sam symbol ${ }^{28}$.

Dla Jaspersa przekazy religijne będą szyframi, a nie symbolami. Tutaj tkwi oryginalność koncepcji Jaspersa, a zarazem źródło dość głośnego onegdaj konfliktu pomiędzy nim a Rudolfem Bultmannem. Ponieważ objętość niniejszego tekstu uniemożliwia mi zdanie szczegółowo sprawy z treści korespondencji pomiędzy tymi wybitnymi myślicielami, dokonam tylko pobieżnego streszczenia owej debaty, mając nadzieję, że pozwoli to uchwycić sedno

\footnotetext{
${ }^{27}$ Jest to jeden z ciekawszych punktów filozofii Jaspersa, który nie został jednak przez niego rozwinięty. Pewne intuicje filozofa możemy uchwycić na podstawie poniższego fragmentu: „Wreszcie możemy chwytać jakby wstecznie pewną świadomość niepodobną ani do zewnętrznego bytu rzeczy, ani do bezprzedmiotowej intencjonalności. Jest to przeżycie czegoś, jako czyste wewnętrzne poruszenie, które czasem może rozbłysnąć nagłą intencjonalnością i w wyniku samego tylko ruchu wstecz wiem o nim, choć samo z braku wszelkiego rozszczepienia (przedmiotowo-podmiotowego) śpi i można je uchwycić jako bycie tu oto (Dasein) tylko w pamięci, np. gdy przeżycie się rozbudza i w niedających się określić uczuciach”, K. Jaspers, Filozofia. Wprowadzenie do filozofii, tłum. M. Żelazny, D. Kolasa, „Filo-Sofija”, nr 1 (9), Bydgoszcz 2009, s. 230. Na taki apojęciowy sposób myślenia o egzystencji zwrócił moją uwagę prof. M. Żelazny.

${ }^{28}$ K. Jaspers, Wiara filozoficzna wobec objawienia, s. 193.
} 
propozycji Jaspersa, która jest w tym miejscu istotniejsza niż szczegółowy przebieg debaty ${ }^{29}$.

Przekaz religijny jest przez osoby wierzące odbierany jako bezpośredni głos Boga, a mówiąc językiem autora Wiary filozoficznej jako transcendencja ucieleśniona. Jaspers stanowczo protestuje przeciwko takiemu ujęciu, wskazując, że odbierałoby ono transcendencji jej transcendentny charakter. Transcendencja, która ma być źródłem wolności człowieka i gwarantem jego możliwość bycia sobą (tu koncepcja Jaspersa nie zaprzecza nauce chrześcijańskiej), stałaby się w takiej sytuacji przedmiotem jednym $\mathrm{z}$ wielu, zdobycie na jej temat wiedzy pozwoliłoby uzyskać nad nią w pewnym sensie kontrolę, co doprowadziłoby do sprzeczności, gdyż możliwość wolności zawdzięczalibyśmy czemuś, co samo nie jest wolne, byłoby bowiem poznawczo „opanowane" przez nas samych. Pozornie może to przypominać teologię negatywną, która nie stara się powiedzieć „czym Bóg jest”, ale odpowiada tylko na pytanie „czym Bóg nie jest”, jednak podobieństwo to jest pozorne. Jaspersowska transcendencja nie może nawet zostać nazwana Bogiem, bo samo określenie „Bóg” jest szyfrem, dodajmy takim, który jest charakterystyczny dla religii wywodzących się z pierwszych ksiąg Starego Testamentu. Skoro zatem niedopuszczalne dla filozofa jest odczytywanie przekazów o Objawieniu jako przekazów o autentycznym objawieniu ${ }^{30}$, które zdarzyło się kiedyś w historii, to Jaspers postuluje odczytanie filozoficzne, w którym religia zostanie potraktowana jako $\mathrm{mit}^{31}$.

${ }^{29}$ Polemika Jaspersa z Bultmannem była przedmiotem analizy innych badaczy, co znalazło wyraz między innymi w następujących publikacjach: G. Matuszczak, Dyskusja pomiędzy teologiem i filozofem. Rudolf Bultmann i Karl Jaspers wobec „demitologizacji” religii, „Filozofia Religii", t. 2, 2006, Uniwersytet im. Adama Mickiewicza, Wydział Teologiczny, Poznań 2006, s. 197-205; J. Miyang Cho, Karl Jaspers' Critique Of Rudolf Bultmann And His Turn Toward Asia; "Existenz. An international journal in philosophy, religion, politics and the arts", vol. 5, 2010, s. 11-15; A. Olson, The succesors and the critics of Karl Jaspers. The Question of myth: Jaspers and Bultmann, [w:] tenże, Transcendence and hermeneutics: An interpretation of the philosophy of Karl Jaspers, M. Nijhoff, The Hague - Boston - London 1979, s. 146-156; N. C. Nielsen Jr., Demythologizing and the philosophia perennis. Bultmann, Jaspers and Heidegger, [w:] Rice University Digital Scholarship Archive, adres WWW: http://scholarship.rice.edu/bitstream/ handle/1911/62871/article_RIP501_part5.pdf?sequence=1 (Dostęp dn. 1 września 2013 r.).

${ }^{30}$ Pisząc „Objawienie”, mam na myśli objawienie chrześcijańskie, natomiast pojęciem „objawienie” nazywam każde bezpośrednie ukazanie się transcendencji (pod postacią jakiegokolwiek bóstwa) w Świecie.

${ }^{31}$ Pewne fragmenty $\mathrm{z}$ powyższego akapitu z powodzeniem dałyby się zastosować również w odniesieniu do Bultmanna, ponieważ jednak to nie tu zasadzało się sedno sporu między myślicielami, pozwolę sobie pominąć szczegółową rekonstrukcję jego poglądów. 
Stajemy przed specyficznym albo-albo:

Objawienie albo jest czasoprzestrzennym określonym działaniem Boga (za jakie uważa objawienie człowiek wierzący), a wówczas nie jest już szyfrem, lecz realnością, albo jest szyfrem, a wówczas występuje obok innych szyfrów i nie jest już realnym objawieniem ${ }^{32}$.

Ujęcie religii jako szyfru, pod postacią mitu, który następnie może zostać przez egzystencję poddany demitologizacji albo przyswojony egzystencjalnie. Jaspers idzie tropem Bultmanna, gdy ten twierdzi, że mitów nie należy odczytywać jako opowieści o realnych wydarzeniach, jednak drogi ich się rozchodzą, gdy pojawia się pytanie, jak należy zatem owe mity interpretować. Jak pisze Roman Rudziński:

Zdaniem Bultmanna pod szatą mityczną ukrywa się prawdziwe słowo Boga, objaśniające i wzywające; trzeba odnaleźć „zasadę hermeneutyczną” reinterpretacji Biblii, która by pozwoliła zrozumieć mit jako prezentację sytuacji człowieka w świecie, objawienie o ludzkiej egzystencji w ogóle, a nie opowieść o realnych zdarzeniach ${ }^{33}$.

Miałoby to oznaczać, że istnieje jakaś „prawdziwa” interpretacja Biblii, której odkrycie pozwalałoby odnaleźć w niej uniwersalną prawdę. Pismo Święte, które przestało być Słowem Bożym stałoby się zatem czymś pomiędzy traktatem z psychologii a podręcznikiem dobrego wychowania. To podejście nie mogło się spotkać z uznaniem Jaspersa przede wszystkim dlatego, że zakładało ono, iż egzystencje ludzkie są czymś ogólnym, do czego da się zastosować takie same zasady etc ${ }^{34}$. Jakże bowiem inaczej wytłumaczyć to, że jedna przypowieść miałaby różnym egzystencjom zdawać sprawę z tego samego faktu dotyczącego ich samych?

${ }^{32}$ K. Jaspers, Wiara filozoficzna wobec objawienia, s. 215. Na marginesie dodajmy, że Jaspers przeciwko wierze w Objawienie wytacza naprawdę potężne działa, nie waha się powiedzieć m.in.: że nadużywa ona (religia) swego autorytetu do kontroli i zabierania wiernym wolności oraz zrywa i uniemożliwia komunikację, co jak wiemy skądinąd, jest w oczach Jaspersa oskarżeniem najpoważniejszym.

${ }^{33}$ R. Rudziński, dz. cyt., s. 235.

${ }^{34}$ Aby być precyzyjnym: chodziło nie tyle o to, że egzystencje jako egzystencje są czymś ogólnym, ile o to, że Bultmann posługiwał się Heideggerowskimi egzystencjałami tak, jakby były to jakieś wyizolowane idee, za pomocą których da się wyjaśnić sytuację człowieka. „Wyjaśnić”, a nie „rozjaśnić”. 
W swej nieprzychylnej recenzji Bultmannowskiej koncepcji demitologizacji Jaspers wychodzi od wskazania jej dwu najważniejszych, jego zdaniem, źródeł. Mają to być: nowoczesna koncepcja nauki i współczesny światopogląd oraz coś, co nazwane zostało „filozofią naukową”. Zdaniem autora Philosophie Bultmann w punkcie wyjścia źle rozumie rolę i zadanie poznania naukowego. Twierdzi on bowiem, że:

Jedność świata w myśleniu naukowym odpowiada samej jedności myślenia naukowego ${ }^{35}$.

Dla Jaspersa takie rozumienie było nie do przyjęcia. Nauki umożliwiają wiedzę o świecie właśnie dlatego, że ujmują go z różnych perspektyw (zatem nie ma mowy o żadnej ich jedności) i w pewnym (niedosłownym) sensie mówią o zupełnie innych światach ${ }^{36}$.

Ostrze krytyki jest skierowane przede wszystkim w sposób, w jaki Bultmann posługiwał się filozofią. Jaspers stawiał oponentowi zarzut głoszący, że ten opiera swoje myślenie o filozofii wyłącznie na Sein und Zeit, a dodatkowo całkowicie błędnie interpretuje dzieło Heideggera, uważając je za „obiektywizujące”, „naukowe” i nieprawidłowo posługuje się pojęciem „,analizy egzystencjalnej". W związku z tym Bultmann miał dokonać nadinterpretacji i całkowicie minąć się z duchem owego dzieła, a ze względu na brak innych filozoficznych punktów odniesienia - duchem filozofii w ogóle. Nie bez racji jest zapewne Alan Olson, gdy wskazuje, że zarzuty Jaspersa brały się w dużej mierze stąd, iż miał on, w oczach autora Wiary filozoficznej, uczyć się filozofii u złego nauczyciela. Chodzi oczywiście o wczesnego Heideggera ${ }^{37}$. Dość jednak powiedzieć, że powyższe czynniki doprowadziły go do odrzucenia koncepcji demitologizacji niemal w całości.

W zamian za to filozof postuluje, aby dokonać „przyswojenia” treści mitu, nawiązać egzystencjalny dialog z jego autorami, dzięki czemu staje się możliwe powtórne odczucie transcendencji, pierwotnie będące udziałem autora mitu (czy w innym aspekcie: autora dzieła literackiego, obrazu, utworu

${ }^{35}$ K. Jaspers, R. Bultmann, Die Frage der Entmythologisierung, Piper Verlag, München 1954, s. 11.

${ }^{36}$ Więcej na temat Jaspersowskiego rozumienia nauki patrz: D. Kolasa, Rola poznania naukowego w filozofii Jaspersa, „Analiza i Egzystencja”, 2012, nr 18, s. 43-57.

${ }^{37}$ A. Olson, The succesors and the critics of Karl Jaspers. The Question of myth: Jaspers and Bultmann, s. 147. 
muzycznego, a także traktatu filozoficznego $\left.{ }^{38}\right)$. Możliwe jest zatem ponowne przeżycie doświadczenia egzystencjalnego, które stało się kiedyś udziałem kogoś innego, a możliwość tę zawdzięczamy wspólnemu zakorzenieniu $\mathrm{w}$ transcendencji. Mit nie jest bowiem czymś przeszłym, ale stanowi immanentny element życia człowieka w każdej epoce ${ }^{39}$. Już Paul Ricoeur zauważył, że kiedy dogmat zostanie przyswojony jako mit, to autorytet stanie się tradycją, której zawdzięczamy umiejętność egzystencjalnego odczytania treści $\mathrm{mitu}^{40}$. Obcowanie z szyframi transcendencji nie polega jednak na interpretacji i pojęciowej systematyzacji mitów i symboli religijnych (tym bowiem mogą zajmować się historia i socjologia religii oraz pokrewne im dyscypliny), ale chodzi o osobiste zaangażowanie. Indywidualne przyswojenie szyfru z jednej strony wymaga zwrócenia się ku swej egzystencji, z drugiej stanowi sposób na jej rozjaśnienie ${ }^{41}$. Mit nie ma zatem być odczytywany przez świadomość w ogóle, ale przemawiać do wolności egzystencji. Dlatego Jaspers uważa, że konieczna jest nie tyle demitologizacja, ile powtórna mitologizacja, czyli uczynienie mitu na nowo mitem. Mit, który jest racjonalizowany, wyjaśniany, w którym znajduje się ogólne metafory i przesłania, nie może przemawiać autentycznie do egzystencji. Mit musi zacząć przemawiać jako szyfr, wówczas może wywierać wpływ na nasze myślenie i działania.

Jest to tym samym odpowiedź na postawione kilka stron wcześniej pytanie o to, czy religia może być prawdziwa w sensie egzystencjalnym. Również na kolejne odpowiedź musi być twierdząca: religia może być źródłem etyki, ale nie $\mathrm{w}$ tym sensie, że poddajemy się jej autorytetowi, lecz w taki sposób, że

\footnotetext{
${ }^{38}$ Musimy pamiętać, że na gruncie filozofii Jaspersa szyfrem może być wszystko, każdy przedmiot materialny i każdy wytwór duchowy człowieka może posiadać swój symboliczny wymiar, w którym nasza wolność „,doświadcza” transcendencji. Por. P. Ricoeur, The relations of Jaspers' philosophy to religion, [w:] P. A. Schilpp, The philosophy of Karl Jaspers, Tudor Publishing Company, New York 1957, s. 620.

${ }^{39}$ K. Jaspers, R. Bultmann, Die Frage der Entmythologisierung, s. 18.

${ }^{40}$ Tamże, s. 625.

${ }^{41}$ K. Jaspers, Wiara filozoficzna wobec objawienia, s. 231. Przy interpretacji zaprezentowanej przez Tomasza Siwca ostateczna demitologizacja miałaby, może nawet wbrew intencji samych autorów, coś wspólnego z koncepcją Jaspersa. Byłoby tym niewątpliwie „przeniesienie” myślenia Boga do wnętrza egzystencji. Ostateczny kompromis nie byłby jednak możliwy, gdyż zdaniem Jaspersa możliwe jest to tylko za pośrednictwem mitu (odczytywanego egzystencjalnie, a nie obiektywizująco), a w myśli Bultmanna to właśnie mit w sposób nieuchronny jest tym, co obiektywizuje. Więcej na temat koncepcji Bultmanna: T. Siwiec, Uwolnić Boga z okowów mitu. Teologia demitologizacji Rudolfa Bultmanna, „Ruch Filozoficzny”, t. LXVI, 2009, z. 3, s. 551-564.
} 
$\mathrm{z}$ tradycji religijnej czerpiemy egzystencjalne punkty odniesienia (bo przecież nie wzorce - nawet „autorytety” z Die Grossen Philosophen mają nas nie tyle „prowadzić”, co pomóc nam wyzwolić nasze własne egzystencjalne możliwości). Jest to charakterystyczne znamię filozofii Jaspersa. Otóż jego zdaniem w ogóle niemożliwe jest „poprowadzenie” kogoś. Nie można kogoś nauczyć filozofowania, można dawać świadectwo swojej własnej drogi, jednak nie po to, by ktoś poszedł taką samą drogą, ale by odnalazł swą własną ${ }^{42}$. A wreszcie, co w świetle powyższego wydaje się oczywiste, nie da rozjaśnić czyjejś egzystencji. Egzystencja jest czymś tak dalece „moim” (de facto egzystencja to ja, a nie coś, co ja „posiadam”), że nikt nie może jej za mnie naprawić. Może to zrodzić oskarżenie o redukcję religii do etyki, jednak łatwo ów zarzut odeprzeć, przyjmując poszerzone, zaproponowane przez Ricoeura rozumienie etyki. Francuski myśliciel nazywa bowiem w tym kontekście etyką „filozofię ludzkiego obcowania ze światem, która jednak rezygnuje z religijnej bezpośredniości” ${ }^{43}$.

Na gruncie zaprezentowanej koncepcji Jezus nic nie traci ze swej wielkości, gdy uznamy, że nie zdarzyło się żadne zmartwychwstanie, a on sam nie był Bogiem wcielonym, a po prostu jednym z największych ludzi. Jego przeżycia i świadectwa o nich mogą bowiem w nie mniejszy sposób przemawiać do egzystencji współczesnego człowieka. Pluralizm Jaspersa polega natomiast na tym, że o ile w sensie, nazwijmy to, faktycznym, wszystkie religie są w równym stopniu fałszywe, co z łatwością daje się wykazać za pomocą metod naukowych, o tyle w aspekcie egzystencjalnym wszystkie mogą być prawdziwe. Ważne jednak, aby traktować je jako szyfry, a nie jako cielesną obecność transcendencji w tym świecie. Pozostaje ostatnia wątpliwość, mianowicie na ile religie te pozostają religiami. Jaspers krok po kroku odrzuca wszystkie wyróżniki doktryn religijnych, poczynając od wspólnotowego charakteru, poprzez poddanie autorytetowi, a na negacji samej możliwości objawienia się transcendencji w świecie kończąc. Wspólna wierze filozoficznej i wierze religijnej pozostaje zatem tylko niezgoda na afirmację immanentnego sensu rzeczywistości.

Religię udaje się zatem ocalić w tym sensie, że pozostaje ona źródłem mitów, które odczytane jako mity mogą pełnić funkcję szyfrów transcenden-

${ }^{42}$ To stanowisko jest niewątpliwie pokłosiem Jaspersowskich rozważań nad filozofią Kierkegaarda i Nietzschego, por. K. Jaspers, Rozum i egzystencja.

${ }^{43}$ P. Ricoeur, s. 613. Roman Rudziński pisze: „Biblia w tej perspektywie może być rozumiana jako zapis ludzkich możliwości egzystencjalnych, ukazujących się dzięki aktywnej partycypacji w jej treściach, a nie poprzez ich reinterpretację". R. Rudziński, s. 236-237. 
cji i przemawiać do wolności, natomiast z pewnością (i tu Jaspers zapewne zgodziłby się ze wspomnianym Bultmannem) religia nie może być już wiarą w jakiś ponadnaturalny świat, którego różne wariacje wpływają na życie w świecie codziennym. Religii, o ile ma być egzystencjalnie prawdziwa, zostaje odebrany supranaturalny pierwiastek i staje się ona jednym z wielu sposobów myślenia o transcendencji. W obrębie terminologii Jaspersowskiej nie jest tak, że słowo „transcendencja” jest synonimem Boga chrześcijańskiego (ujęcie, $\mathrm{z}$ którym można spotkać się $\mathrm{w}$ powierzchownych interpretacjach filozofii Jaspersa). Sprawa wygląda dokładnie odwrotnie - to „Bóg” jest jednym ze sposobów, w jaki wyrażamy to, co jest faktycznie niewyrażalne, czyli transcendencję. Podobną "rolę" mogą odgrywać także „bogowie greccy”, „filozoficzny Absolut”, „Idee Platona”, „Jednia Plotyna”, „świat jako całość, „samostanowiąca się historia”, „rzecz sama w sobie” i wiele, wiele innych. Wszystko to są przejawy głębokiego uchwycenia niewystarczalności człowieka dla siebie samego i skutki poszukiwań źródeł wolności. Doświadczenie to stało się udziałem także samego Jaspersa, dlatego tak bardzo próbował w symbolicznej postaci wyrazić tęsknotę za transcendencją niemożliwą do wyrażenia w jakichkolwiek pojęciach. Efektem tego była filozoficzna koncepcja szyfrów transcendencji, będąca sama, nomen omen szyfrem transcendencji, który może zostać teraz odczytany przez kogoś, kto wejdzie z Jaspersem w swoisty filozoficzny dialog i odnajdzie w jego myśli tę samą wolność, której doświadcza u siebie.

\section{Bibliografia}

Cho J.M., Karl Jaspers' Critique Of Rudolf Bultmann And His Turn Toward Asia;

"Existenz. An international journal in philosophy, religion, politics and the arts", Volume 5, 2010.

Garaudy R., Perspektywy człowieka, tłum. Butkiewicz Z., Rogoziński J., Książka i Wiedza, Warszawa 1968.

Jaspers K., Autobiografia, tłum. Turowicz S., Wydawnictwo COMER, Toruń 1993.

Jaspers K., Autorytety. Sokrates, Budda, Konfucjusz, Jezus, tłum. Bentkowski P., Flaszak R., Wydawnictwo KR, Warszawa 2000.

Jaspers K., Die großen Philosophen. Nachlass Bd 1, Darstellungen und Fragmente, zebrane i zredagowane przez Hansa Sanera, Piper, München 1981.

Jaspers K., Filozofia egzystencji, tłum. Lachowska D., Wołkowicz A., Państwowy Instytut Wydawniczy, Warszawa 1990.

Jaspers K., Filozofia. Wprowadzenie do filozofii, tłum. Żelazny M., Kolasa D., „Filo-Sofija”, nr 1 (9), Bydgoszcz 2009. 
Jaspers K., Rozum i egzystencja. Nietzsche i chrześcijaństwo, tłum. Piecuch Cz., Wydawnictwo Naukowe PWN, Warszawa 1991.

Jaspers K., Strindberg i Van Gogh. Próba analizy patograficznej z porównawczym przywołaniem Swedenborga i Hölderlina, tłum. Reszke R., Wydawnictwo KR, Warszawa 2006.

Jaspers K., Szyfry transcendencji, tłum. Piecuch Cz., Wydawnictwo COMER, Toruń 1995.

Jaspers K., Wiara filozoficzna, tłum. Buchner A. i inni, Wydawnictwo COMER, Toruń 1995.

Jaspers K., Wiara filozoficzna wobec objawienia, tłum. Sowiński G., Wydawnictwo ZNAK, Kraków 1999.

Jaspers K., Wprowadzenie do filozofii. Dwanaście odczytów radiowych, tłum. Wołkowicz A., Siedmioróg, Wrocław 1998.

Jaspers K., Bultmann R., Die Frage der Entmythologisierung, Piper Verlag, München 1954.

Kierkegaard S., Die Tagebücher, tłumaczenie z duńskiego na niemiecki i redakcja naukowa Theodor Haecker, Brenner Verlag, Innsbruck 1923.

Kirkbright S., Karl Jaspers. A biography. Navigations in truth, Yale University Press, New Haven and London 2004.

Kolasa D., Rola poznania naukowego w filozofii Jaspersa, „Analiza i Egzystencja”, nr 18, Szczecin 2012.

Kolasa D., Sytuacje możliwe a sytuacje graniczne w filozofii Karla Jaspersa, „Studia z Historii Filozofii" nr 1, Toruń 2009.

Malhorta M. K., Die Philosophie Karl Jaspers' und die indische Philosophie, „Zeitschrift für philosophische Forschung”, Frankfurt am Main 1961.

Marcel G., Od sprzeciwu do wezwania, tłum. Ławicki S., Instytut Wydawniczy PAX, Warszawa 1965.

Matuszczak G., Dyskusja pomiędzy teologiem i filozofem. Rudolf Bultmann i Karl Jaspers wobec „demitologizacji” religii, „Filozofia Religii”, t. 2/2006, Uniwersytet im. Adama Mickiewicza, Wydział Teologiczny, Poznań 2006, s. 197-205.

Mounier E., Wprowadzenie do egzystencjalizmów oraz wybór innych prac, tłum. Zabłocki J., Znak, Kraków 1964.

Nielsen N. C. Jr., Demythologizing and the philosophia perennis. Bultmann, Jaspers and Heidegger, [w:] Rice University Digital Scholarship Archive, dostęp dn. 1 września 2013 r., adres WWW: http://scholarship.rice.edu/bitstream/handle/1911/62871/ article_RIP501_part5.pdf?sequence $=1$.

Olson A., Jesus as "Paradigmatic individual" in Karl Jaspers' Great Philosophers, Vol. 1, "Existenz. An international journal in philosophy, religion, politics and the arts", Volume 2, 2007.

Olson A., Transcendence and hermeneutics: An interpretation of the philosophy of Karl Jaspers, M. Nijhoff, The Hague-Boston-London 1979. 
Piecuch Cz. (red.), Karl Jaspers: człowiek w epoce przełomu, Wydawnictwo Naukowe Uniwersytetu Pedagogicznego, Kraków 2013.

Piecuch Cz. (red.), Karl Jaspers. Myślenie zaangażowane, Wydawnictwo Naukowe Uniwersytetu Pedagogicznego, Kraków 2011.

Rudziński R., Człowiek w obliczu nieskończoności. Metafizyka i egzystencja w filozofii Karla Jaspersa, Książka i Wiedza, Warszawa 1980.

Rudziński R., Jaspers, Wiedza Powszechna, Warszawa 1978.

Salamun K., Walters G., Karl Jaspers philosophy: Expositions \& interpretations, Humanity Books, Amherst, New York 2008.

Schilpp P. A., The philosophy of Karl Jaspers, Tudor Publishing Company, New York 1957.

Siwiec T., Uwolnić Boga z okowów mitu. Teologia demitologizacji Rudolfa Bultmanna, „Ruch Filozoficzny”, t. LXVI, z. 3, Toruń 2009.

Sopoliński M., Między filozofia a chrześcijaństwem. Z filozofii religii Karla Jaspersa, „Filozofia religii”, t. 1, Poznań 2005.

Wautischer H., Olson A., Walters G., (ed.), Philosophical faith and the future of humanity, Springer, Dordecht-Heidelberg-London-New York 2012.

Żelazny M., Filozofia i psychologia egzystencjalna, Wydawnictwo Naukowe UMK, Toruń 2011.

\section{Abstract \\ Pluralism in Karl Jaspers' Philosophy of Religion}

Although Karl Jaspers was not a practicing Christian, a religion has always been a very important part of his considerations. The philosopher rejected the truth of revelation, but believed that faith can be very important part of human life. What we call "philosophy of religion" in Jaspers thought is not reflection about religious revelation, but consist of inquires about faith in that revelation. Author tried to ascertain if on the ground of Jaspers's philosophy, religion, not being true in scientific sense, can be true in other sense and if so - what sense of truth would it be. In wider perspective the question is: what "the truth of religion" means? Author shows similarities and dissimilarities between religious faith and Jaspers' concept of philosophical faith.

Key words: existenz, religion, transcendence, philosophy of existenz, Karl Jaspers, cipher 